\title{
Uses and Properties of some Adverbs in Contemporary French and Spanish: honnêtement and sérieusement vs. honestamente, seriamente and en serio
}

\author{
Emma Álvarez-Prendes (Oviedo)
}

\begin{abstract}
In this paper we propose to examine and contrast the functioning of five adverbs in contemporary French (sérieusement and honnêtement) and Spanish (honestamente, seriamente and en serio). Our aim is threefold:

- To verify the different uses of honnêtement and sérieusement in French, and to compare them with the uses of honestamente, seriamente and en serio in Spanish.

- To justify the existence of these uses in terms of their different properties.

- To examine the origin and historical evolution of these uses and to explain their common origin as a result of a process of subjectification.
\end{abstract}

\section{Introduction}

Following our previous work on the uses and properties of the French adverbs sérieusement (cf. Álvarez-Prendes 2016) and honnêtement (cf. Álvarez-Prendes 2018), we decided to extend our research to their Spanish counterparts (namely, honestamente, seriamente and en serio) in order to carry out a contrastive study. We set out to address the relationship between uses and properties that exist in both languages, as well as to compare the parallel uses in French and Spanish (honnêtement vs honestamente, sérieusement vs seriamente and en serio).

Our research deals with both syntax and semantics, since we have used syntactic (i. e. extraction via $c^{\prime}$ est...que, the possibility of preceding a negative phrase, the possibility of being the focus of negation, etc.) and semantic tests (i. e. several possibilities of paraphrasing, linking, etc.) to reveal uses and properties. Our examples are drawn from a personal corpus, which includes several hundred occurrences, sourced from various databases (i.e. FRANTEXT or the corpus of Le Monde in the case of French, Corpus de Referencia del Español Actual [CREA] in the case of Spanish), as well as other journalistic, oral and Internet sources. The initial idea when creating the corpus was to cover a large variety of uses and language registers (oral/written discourse, formal/informal discourse, etc.), and avoid limiting our study to only one of them. 
Regarding the theoretical framework, our research is in the field of non-truth-conditional semantics, particularly integrated pragmatics (cf. Anscombre/Ducrot 1983), whereby words carry instructions beyond their purely semantic meaning, conditioning their sequence in the sentence and allowing us to explain the meaning of the statement.

Our starting hypothesis is that the French adverb honnêtement shares two uses and, to a great extent, the properties of the Spanish adverb honestamente. However, the former can also display a third function as an adverb of degree which is ignored by its Spanish counterpart. In the same way, the French adverb sérieusement shares some uses and properties of two Spanish adverbs: seriamente and en serio, but none of them have the three uses displayed by the French adverb.

Before we begin the main body of our work, we should point out that adverbs have long been considered an extremely heterogeneous class which defies simple definition (Wilmet 1997). Whereas there is an abundance of descriptive and classifying work on adverbs ending in -ly/ment/mente (cf. Klinkenberg 1933 [1928]; Quirk/Greenbaum 1973; Mørdrup 1976; Schlyter 1977; Mélis 1983; Molinier 1990; Guimier 1996; Kovacci 1999; Molinier-Levrier 2000; Gezundhajt 2000; Rodríguez Ramalle 2003; etc.), the individual analysis of -ment/-mente adverbs, has, until recently, been scarcer, with contrasting analysis being even more infrequent.

\section{2 honnêtement vs honestamente: function and properties}

Based on the application of a series of linguistic tests (tests largely carried out by Schlyter, 1977 and Molinier-Levrier 2000), we have detected three different functions for the adverb honnêtement in French and two uses for the adverb honestamente in Spanish:

1. An adverb of manner referring to the subject, characterizing the fulfilment of an action asserted by the verb in the statement:

- Mais personne ne croira que je l'ai gagnée honnêtement; on dira que je l'ai volée, c'est qu'on ne prête pas aux pauvres.

'- But no one will believe that I have earned it honestly - people will think I've stolen it because no one lends things to the poor.'

Se trata de aplicar la política neoliberal honestamente.

'It is about applying neoliberal politics honestly.'

2. (only in French) An adverb of degree or intensity, indicating an average, or slightly greater than average degree with regard to the content of the adjective which it modifies:

Ce portable n'est certes pas minuscule mais reste tout à fait honnêtement petit!.

'This mobile phone is definitely not tiny but it is still reasonably small!'

3. Finally, a statement adverb, showing the speaker's attitude towards his or her own statement:

- Honnêtement, je ne le regrette pas! Je ne renie rien! J'en connaissais les conséquences, mais j'ai fait ce qui me semblait essentiel de faire pour dénoncer le cancer que représente la Mafia au niveau mondial. 
'- To be honest, I don't regret it! I deny nothing! I knew the consequences, but I did what I thought I had to do to report the cancer which the Mafia represents worldwide.'

He recibido amenazas, pero honestamente no las tomo muy en serio.

'I've received threats, but to be honest, I don't take them very seriously. Nothing is going to happen.'

We shall now consider the characteristics of these uses.

\section{1 honnêtement}

\subsection{1 honnêtement}

We can have a look at a few examples of the first function of the French adverb honnêtement:

1. - Jean-Louis Curtis est totalement oublié aujourd'hui. Il a écrit une quinzaine de romans, des nouvelles, un recueil de pastiches extraordinaire... La France m'épuise contient, à mon avis, las pastiches las plus réussis de la littérature française: ses imitations de Saint-Simon, de Chateaubriand sont parfaites; il se débrouille très bien aussi avec Stendhal et Balzac. Et pourtant aujourd'hui il n'en reste rien, plus personne ne le lit. C'est injuste, c'était plutôt un bon auteur, dans un genre un peu conservateur, un peu classique, mais il essayait de faire honnêtement son travail, enfin ce qu'il estimait être son travail (Houellebecq, 2010).

- 'Jean-Louis Curtis has been completely forgotten nowadays. He wrote about fifteen novels, short stories, a wonderful collection of pastiches ... In my opinion, La France m'épuise includes the most successful pastiches in French literature: his imitations of Saint Simon and Chateaubriand are perfect, and he also deals with Stendhal and Balzac very well. And yet nothing remains nowadays - no one reads his works any more. It is not fair as he was a good author in a genre that was a little conservative, a little classic. Nevertheless, he tried to carry out his work honestly - what he finally believed to be his work.'

2. - Prends-la, je te la donne.

- C'est trop.

- Ce n'est pas trop puisque tu n'as rien.

- Mais personne ne croira que je l'ai gagnée honnêtement; on dira que je l'ai volée, c'est qu'on ne prête pas aux pauvres (Schmitt, 1994).

'- Take it. It's yours.

- It's too much.

- It's not too much because you have nothing.

- But no one will believe that I have earned it honestly - people will think I've stolen it because no one lends things to the poor.'

3. - As-tu la maladie du transfert?

Comprenant qu'il doit s'agir d'une névrose typiquement divine consistant à se prendre pour son peuple, je réponds le plus honnêtement possible. (Weber, 2005).

'- Do you suffer from transference neurosis?' 
Considering that it must be a typical divine neurosis that consists of believing oneself to be their people, I answer as honestly as possible'

4. À vous de choisir, donc: mourir ou raconter. Je reviendrai dans une semaine. Mais je vous préviens honnêtement: ma famille, il faut se la faire! (Pennac, 1997 a).

'You choose - die or tell. I will be back in a week. But I honestly warn you: my family is a nuisance!'

5. Des négociants en vin de Bernheim, en Alsace, qui trafiquent honnêtement leur sylvaner au gros plant nantais. Ils ont déshérité Krämer au profit de leurs deux aînés. (Pennac, 1997 b).

'Wine merchants from Bernheim in Alsace who honestly traffic in their Sylvaner for Gros Plant du Pays Nantais. They have disinherited Krämer in favor of their two eldest children.'

This use displays the following linguistic properties:

a) Syntactic properties:

prop $_{1}$ : honnêtement ${ }_{1}$ has a surface structure $\mathrm{H}(\mathrm{X})$, where $\mathrm{H}$ stands for the adverb honnêtement and $\mathrm{X}$ for the predicate it modifies.

prop $_{2}$ : honnêtement 1 can be extracted in a cleft sentence:

1a. C'est honnêtement qu'il essayait de faire son travail.

2a. Personne ne croira que c'est honnêtement que je l'ai gagnée.

3a. C'est le plus honnêtement possible que je réponds.

This criterion shows how honnêtement ${ }_{1}$ can be the focus of the sentence.

prop3: it can also be the focus of a negation:

1b. Il essayait de faire son travail mais il n'essayait pas de le faire honnêtement.

3b. Je réponds mais je ne réponds pas le plus honnêtement possible.

5b. Des négociants en vin de Bernheim, en Alsace, qui trafiquent leur sylvaner au gros plant nantais, mais que ne le trafiquent pas honnêtement.

prop4: it can stand alone as a response:

6. Comment a-t-il gagné son argent? Honnêtement.

'How has he earned his money? Honestly.'

b) Semantic-pragmatic properties:

prop5: honnêtement 1 always modifies a verb; therefore it can be paraphrased by de (d'une) manièrelfaçon + Adj (honnête):

1c. Il essayait de travailler de façon honnête.

4c. Je vous préviens de façon honnête.

5c. Je réponds de la manière la plus honnête possible. 
prop6: honnêtement 1 establishes a relationship between a verb and a noun phrase fulfilling the role of agent. It appears like this with agent verbs and can be paraphrased in French by the verb faire (Schlyter 1977):

1e. Il essayait de le faire [= travailler] honnêtement.

2e. Personne ne croira que je l'ai fait [= gagner] honnêtement.

3e. Je le fais [=vous répondre] le plus honnêtement possible.

Taking all these properties into account, we can set that this very first use is that of a constituent adverb, which has a syntactic function within the sentence and (for the advocates of truth-conditional semantics) has also an incidence in the truth conditions of the sentence. More precisely, this use responds to the properties of an adverb of manner, which establishes the way an action has been accomplished. This use corresponds then to what Mørdrup (1976) calls "adverbs of manner"; Schlyter (1977), "verbal adverbs"; or Molinier (1990) and Molinier and Levrier (2000: 50), "adverbs of manner referring to the subject".

\subsection{2 honnêtement}

Another function we have identified is that of a constituent adverb like honnêtement ${ }_{1}$, but in this case the adverb conveys an average, or slightly above average degree in relation to the adjective content or the verb being modified.

We shall illustrate this use with examples taken from our corpus:

7. En tout cas avec ses $113 \times 48 \times 19 \mathrm{~mm}$, ce portable n'est certes pas minuscule mais reste tout à fait honnêtement petit ! Il est aisément transportable et ne gêne absolument pas dans une poche de pantalon!

(www.ciao.fr/Nokia_3410_Avis_465494,[20.02.2015]).

'This mobile phone is definitely not tiny but it is still reasonably small!'

8. Le concept de MOOC est très intéressant, et même honnêtement beau. (MOOC: Révolution ou Supercherie?, 2014).

'The concept of MOOC is very interesting and reasonably good at the same time.'

9. Une poussette doit être honnêtement spacieuse pour permettre les mouvements du corps tels que le changement dans la place. (http://www.etichete.info/poussette-a-cannexzoga.htm, [20.02.2015])

'A buggy must be reasonably spacious so as to allow body movements such as changing the baby's nappy on the spot.'

10. Si la tranche à huit ans 9,50\% nominal et 9,85\%, plutôt réservée aux investisseurs institutionnels, s'est honnêtement placée, sans plus, celle à dix ans, 10\% nominal et 9,96\% réel, plutôt destinée aux guichets des réseaux Poste et banques, a été très demandée et le restait à la veille du week-end (Corpus Le Monde).

'If the nominal rate of $9.50 \%$ and $9.85 \%$ for eight years, which is rather reserved for institutional investors, was fairly deposited, nothing more, for ten years with a nominal rate of $10 \%$ and a real rate of $9.96 \%$, rather reserved for post offices and banks, it would be very much in demand and continue to be so on the day before the weekend.' 
11. Le vocabulaire traduit bien l'imprécision dans laquelle se trouve le public honnêtement cultivé mais non spécialiste. (Corpus Le Monde).

'Vocabulary translates well the imprecision of the public who is reasonably cultured but not specialized.'

We can confirm the existence of this second use of honnêtement with the help of the following criteria:

a) Syntactic properties:

prop1: honnêtement ${ }_{2}$ has a surface structure $\mathrm{H}(\mathrm{X})$.

prop2: honnêtement 2 cannot appear at the head of a sentence:

7a. * Honnêtement, il était tout à fait petit.

8a. * Honnêtement, il est même beau.

9a. * Honnêtement, elle doit être spacieuse.

prop $_{3}$ : honnêtement 2 can be the focus of a negation:

7b. Il était petit mais pas honnêtement petit.

8b. Il était beau mais pas honnêtement beau.

9b. Elle est spacieuse, mais pas honnêtement spacieuse.

prop $_{4}$ : it modifies an adjectival form. In such cases, honnêtement 2 appears before the adjective it modifies (cf. examples 7-9 and 11), or between the end verb and the past participle (cf. example 10). The postposition of the adverb would usually turn it into an adverb of manner (= honnêtement $\left.)_{1}\right)$ :

12. Elle s'est honnêtement placée (= correctly) vs. Elle s'est placée honnêtement (= in an honest manner);

13. C'est honnêtement petit vs * C'est petit honnêtement (the only possible reading here is that of a statement adverb if there were a pause between the adjective and the adverb).

prop $_{5}$ : honnêtement ${ }_{2}$ admits the possibility of degree (superiority): C'est plus qu'honnêtement Adj.

7d. C'est plus qu'honnêtement petit.

8d. C'est plus qu'honnêtement beau.

9d. Une poussette doit être plus qu'honnêtement spacieuse pour permettre les mouvements du corps.

b) Semantic-pragmatic properties:

prop $_{6}$ : honnêtement 2 allows for a "surenchérissement" by means of et même:

7e. C'est honnêtement petit, et même minuscule.

8e. C'est honnêtement beau, et même splendide.

9e. Elle doit être honnêtement spacieuse, et même très spacieuse. 
Considering all these properties, we can state that this second use is - as is the first use - that of a constituent adverb, which has a syntactic function within the sentence and has also an incidence in the truth conditions of the sentence; but contrary to what happens with honnetement $t_{1}$, in this case it is an adverb of degree, which conveys an average, or slightly above average degree in relation to the adjective content being modified (and not the characterization of the process stated by the verb, as is the case for honnetement ${ }_{1}$, cf. 2.1.1). This use corresponds to what Schlyter (1977) refers to as an "adverb of degree"; or Molinier (1990), as “a quantifying adverb of manner".

\subsection{3 honnêtement ${ }_{3}$}

The last use of honnetement that we have detected is a completely different use: that of a sentence adverb, or rather it is an enunciative adverb which expresses the speaker's comment on the way that he says something.

We shall now turn to several examples sourced from our corpus of honnêtement 3 :

14. - Honnêtement, je ne le regrette pas! Je ne renie rien! J'en connaissais les conséquences, mais j'ai fait ce qui me semblait essentiel de faire pour dénoncer le cancer que représente la Mafia au niveau mondial. (Psenny, 2015).

'- To be honest, I don't regret it! I deny nothing! I knew the consequences, but I did what I thought I had to do to report the cancer which the Mafia represents worldwide.'

15. Elle avait trouvé un endroit où elle se sentait bien. Pas juste pour passer l'été en attendant de se refaire une vie sociale. Honnêtement, elle était bien avec Magali et sa cour d'improbables (Despentes, 2010).

'She had found a place where she felt at ease. Not only to spend the summer waiting to rebuild her social life. To be honest, she was fine with Magali and her inner circle of improbable admirers.'

16. Ce sont des défenses perverses, monsieur Dugain. C'était ça ou devenir fou.

- Mais tu es fou, Al, fou à lier.

- Honnêtement, je ne crois pas. J'ai dressé des défenses perverses pour ne pas le devenir alors que tout m'y poussait. Je n'ai pas de psychose établie, les experts m'ont suivi sur ce point. (Lemaitre, 2013).

'These are perverse defenses, Monsieur Dugain. It was that or going mad.

- But you are mad, Al, mad as a hatter.

- To be honest, I don't think so. I've built these perverse defenses so as not to become mad even though everything pushed me towards madness. I don't have an established psychosis; the experts have followed me up on this subject.'

17. L'administration n'ouvre jamais son courrier. C'est comme cela que ces photos lui parviennent. Il les conserve sur son étagère mais, très honnêtement, il ne les regarde jamais. (Peras, 2012).

'Managers never open their mail. That is how he received these photos. He keeps them on his shelf, but to be quite honest he never looks at them.'

18. Elle a redémarré calmement en adoptant une voix doucereuse: 
- Qu'est-ce que tu comptes faire?

- Très honnêtement, je n'y avais pas encore pensé. Je voulais faire quelque chose dans le domaine de la moto ou un travail au grand air mais mon désir n'était pas plus précis (Dugain, 2012).

'She calmly started again by adopting a sweet voice:

- What are you planning on doing?

- To be quite honest, I haven't thought about it yet. I wanted to do something related to motorbikes or working in the fresh air, but my wish wasn't that clear.'

We can now examine the linguistic properties of this use:

a) Syntactic properties:

prop $_{1}$ : honnêtement 3 corresponds to a surface structure $\mathrm{H}(\mathrm{X}, \mathrm{Y})$, where $\mathrm{H}$ stands for honnêtement and $\mathrm{X}$ and $\mathrm{Y}$ for two different material segments, and whose canonical structure would be of the type: X honnetement ${ }_{3} \mathrm{Y}$.

prop $_{2}$ : unlike honnêtement ${ }_{1}$ and honnêtement ${ }_{2}$, honnêtement $t_{3}$ can appear in detached position at the head of a negative sentence:

14a. Honnêtement, je ne le regrette pas !

15a. Honnêtement, elle n'était pas bien avec Magali et sa cour d'improbables

16a. Honnêtement, sans vouloir vous contrarier, je ne crois pas.

prop $_{3}$ : unlike honnêtement ${ }_{1}$, it cannot be extracted by $C^{\prime}$ 'est ... que.

14b. * Ce n'est pas honnêtement que le regrette.

15b. * C'est honnêtement qu'elle était bien avec Magali.

16b. * Ce n'est pas honnêtement que je le crois.

prop $_{4}$ : unlike honnêtement $t_{1}$ and honnêtement ${ }_{2}$, honnêtement $t_{3}$ cannot be the focus of a negation: as a corollary of its independence from propositional content, it is never within the scope of a negation.

14c. * Je le regrette mais je ne le regrette pas honnêtement.

15c. * Elle est bien avec Magali, mais elle n'est pas honnêtement bien avec elle.

16c. * Je le crois mais je ne le crois pas honnêtement.

prop $_{5}$ : it can appear at the head of almost any type of sentence: declarative affirmative (cf. example 15) and negative (cf. examples 14, 16 and 18), interrogative (cf. example 19) and even imperative (cf. example 20).

19. Honnêtement, il peut s'en sortir? (Honnêtement, il peut s'en sortir, 2014).

'Honestly, can he get out of this?'

20. Honnêtement, enlève ce chapeau! Il ne te va pas du tout.

'Honestly, take off that hat! It doesn't suit you at all.' 
prop $_{6}$ : honnêtement ${ }_{3}$ appears especially at the head of a sentence (in initial detached position cf. examples 14-16 and 18). It also appears frequently in embedded position (cf. example 17) or final position (cf. example 21).

\section{Ce n'est pas crédible honnêtement?}

'Isn't it really believable?'

b) Semantic-pragmatic properties:

prop $_{7}$ : honnêtement ${ }_{3}$ can be paraphrased in French by: Ce que je fais honnêtement c'est te dire que $\mathrm{P}$ or Je suis honnête en te disant que $\mathrm{P}$ (where $\mathrm{P}$ takes up the content of the stated proposition).

14d. Ce que je fais honnêtement c'est te dire que je le regrette.

14e. Je suis honnête en te disant/lorsque je te dis que je le regrette.

16d. Ce que je fais honnêtement c'est te dire que je le crois.

16e. Je suis honnête en te disant/lorsque je te dis que je le crois.

prop $_{8}$ : honnêtement 3 has an inherent dialogic semantic structure; therefore its semantic structure of this operator is usually $\mathrm{p}$ honnêtement $\mathrm{z}_{3} \mathrm{q}$, where $\mathrm{p}$ and $\mathrm{q}$ refer to opposing propositional content. Those opposing propositional contents can be both actualized in the sentence (cf. example 16: $\mathrm{p}=$ Vous êtes fou vs. $\mathrm{q}=$ Je ne crois pas être fou), or they may remain virtual. For instance, in a sentence like J'ai rencontré un homme et, honnêtement, il m'a plu 'I met a man and, to be honest, I liked him', the adverb honnêtement introduces q (= il m'a plu), which is opposed to a virtual content $\mathrm{p}$ also actualized by the adverb; this $\mathrm{p}$ content could be something like cet homme ne m'a pas du tout plu 'I didn't like this man at all'. The presence of honnêtement in the sentence triggers an interpretation of q which goes against what may be the initial expectations of the addressee (i. e. cet homme ne t'a pas plu, cet homme ne t'as pas beaucoup plu, etc.). The opposition between those two contents would be indeed actualized by the adverb.

This third use of honnêtement is that of a sentence adverb, which does not have its scope within the sentence (as is the case for prop $_{2}$ and prop $_{3}$ ) and (for the advocates of truthconditional semantics) has no incidence in the truth conditions of the sentence. More precisely, we are dealing here with an enunciative adverb, which, according to Molinier (2009), allows the speaker to highlight the particular conditions surrounding the utterance of his statement and constitutes a kind of personal comment on behalf of the speaker; Ducrot points out (1980) that an adverbe d'énonciation qualifies the statement in which the utterance has appeared and gives it a certain character (i. e. a serious character in those examples). This use corresponds to the "style disjuncts" referenced in Mørdrup (1976), Molinier (1990), or Molinier and Levrier (2000) ${ }^{1}$; to Schlyter's "relationship adverbs" (1977); to the "enunciative adverbs" of Ducrot (1980), Nølke (1993), and Molinier (2009); as well as to the extrapredicative exosentential adverbs concerning the purpose of illocutive type discourse, by Guimier (1996). 


\section{2 honestamente}

Let us turn to an analysis of the adverb honestamente, the equivalent of honnêtement in Spanish. Contrary to what happened with the French adverb, we have identified only two uses of honestamente: one as an adverb of manner and another as a statement adverb. There is no possibility of honestmaente functioning as an adverb of degree in Spanish.

\subsection{1 honestamente ${ }_{1}$}

To start with, we shall consider some examples of this first functioning taken from the Corpus de Referencia del Español Actual (CREA):

22. Lo importante es que se haga honestamente y con transparencia y que quien cometa un error, una ilegalidad, lo pague.

'The important thing is that it is done honestly and transparently and that the person that makes a mistake or does something illegal, pays for it.'

23. Se trata de aplicar la política neoliberal honestamente.

'It is about applying neoliberal politics honestly.'

24. Sandra era el espíritu del 68, yo estaba actuando muy honestamente con ella, y si esta gringa ignorante no mete la pata de puro andar siguiendo slogans y no lo que son realmente sus sentimientos, con ella, por ella, ante ella, y a través de ella, sobre todo, podía reconciliarme con el presente, modernizarme y reconstruirme para caer de cabeza y feliz y poblado de buenas intenciones entre las celestiales antorchas de las barricadas. 'Sandra was the spirit of 68. I was behaving very honestly with her, and if this ignorant gringo does not put her foot in it by following slogans and not her real feelings, with her, for her, before her and through her, mainly, I could reconcile myself with the present, modernise and rebuild myself to fall head first and happy and full of good intentions within the celestial torches of the barricades.'

25. El control ilegal clandestino, continuado y sistemático de los ciudadanos sólo puede tener como fin la extorsión, la discriminación o en suma el menoscabo de la libre formación de la voluntad de los ciudadanos, no existiendo móviles alternativos que puedan justificar honestamente tal conducta.

'The purpose of illegal clandestine, continuous and systematic control of citizens can only be the extortion, discrimination or, in short, the damage of the free formation of citizens' will; not existing alternative motifs which may honestly justify such behaviour.'

26. ¿Quién nos informa honestamente sobre unas dudosas elecciones en Rusia?

'Who does honestly inform us about dubious elections in Russia?'

We have identified the following linguistic properties regarding its use:

a) Syntactic properties:

prop $_{1}$ : honestamente ${ }_{1}$ has a surface structure $\mathrm{H}(\mathrm{X})$.

prop $_{2}$ : it cannot go in sentence-initial position:

22a. * Honestamente lo importante es que se haga. 
23a. * Honestamente se trata de aplicar la política neoliberal.

24a. * Honestamente yo estaba actuando con ella.

prop $_{3}$ : it can be the focus of a negation:

22b. Lo importante es que se haga, pero no que se haga honestamente.

23b. Se trata de aplicar la política liberal, pero no de aplicarla honestamente.

24b. Yo estaba actuando con ella, pero no estaba actuando honestamente.

prop $_{4}$ : it can stand alone as a response:

27. ¿Cómo ganó su dinero? Honestamente.

b) Semantic-pragmatic properties:

prop $_{5}$ : honestamente ${ }_{1}$ always modifies the verb and can be paraphrased by de maneralforma + Adj (honesta):

22c. Lo importante es que se haga de manera honesta.

23c. Se trata de aplicar la política neoliberal de forma honesta.

24c. Yo estaba actuando con ella de forma honesta.

prop $_{6}$ : honestamente ${ }_{1}$ involves verbs which establish a relationship between a verb and a noun phrase in the form of an agent. It appears in this way with agent verbs allowing for the paraphrase hacer:

23d. Se trata de hacerlo [= aplicar la política neoliberal $]$ honestamente.

24d. Yo estaba haciéndolo [= actuar $]$ honestamente.

In this use we are dealing with a constituent adverb which characterizes the fulfilment of the process stated by the verb in the statement, or in another words, with an adverb of manner, as it was also the case previously for honnêtement ${ }_{1}$.

\subsection{2 honestamente h $_{\mathrm{x}}$}

We have found no examples of honestamente in Spanish as an adverb of degree or an intensifying adverb.

\subsection{3 honestamente ${ }_{3}$}

The second use of honestamente in Spanish is the same as honnêtement 3 in French, which functions as an enunciative adverb.

Here are a few examples from our corpus taken from CREA:

28. He recibido amenazas, pero honestamente no las tomo muy en serio. No pasará nada. 'I've received threats, but to be honest, I don't take them very seriously. Nothing is going to happen.' 
29. Dirigir en un Mundial es el sueño de cualquier entrenador y también es el mío. Esa sería la culminación de mi carrera, porque, honestamente, no pretendo seguir vegetando y sufriendo en el fútbol hasta los 60 años o más.

'Taking part in a World Championship is the dream of any coach, and also mine. It would be the culmination of my career because, to be honest, I don't expect to carry on vegetating and suffering in football until I'm 60 or older.'

30. La decisión de mantenerlo en el banquillo ya destituido ha sido del presidente la cual todos respetamos. Si al entrenador no le importaba, a mí tampoco, aunque, honestamente, no es bueno.

'The decision of keeping him on the bench when he was already dismissed, which we all respect, has been made by the president. If the coach didn't mind, neither did I, although, to be honest, he isn't any good.'

31. Vamos a la presentación de nuestra protagonista que creo que Kim lo ha entendido al revés, honestamente. Todo lo que les ha contado es mentira.

'Let's introduce our main character that I honestly think that Kim has completely misunderstood. Everything she has told you is a lie.'

32. María del Monte no pierde los cinco kilos que le sobran por respeto a su público que la prefieren rellenita. Yo honestamente la veo de maravilla así.

'María del Monte hasn't lost the five extra kilos out of respect for her public who prefer her to be a little plump. I honestly think she looks wonderful as she is.'

We shall look closely now at the linguistic properties of honestamente ${ }_{2}$ :

a) Syntactic properties:

prop $_{1}$ : honestamente 2 corresponds to a surface structure $\mathrm{H}(\mathrm{X}, \mathrm{Y})$, whose canonical version is of the type: X honestamente 2 Y.

prop $_{2}$ : unlike honestamente ${ }_{1}$, honestamente 2 can appear in detached position at the head of a negative sentence:

33. Honestamente, yo no la veo de maravilla así.

prop $_{3}$ : unlike honestamente 1 , it cannot be the focus of a negation:

28b. * Ha recibido amenazas pero no las ha recibido honestamente.

prop $_{4}$ : it can appear at the head of any type of sentence: declarative affirmative (cf. example 33) and negative (cf. example 34), interrogative (cf. example 35) and even imperative (cf. example 36).

34. Honestamente, no recuerdo los nombres.

'To be honest, I can't remember the names.'

35. Honestamente, ¿te ha costado mucho?

'Honestly, was it very difficult/expensive?'

36. Honestamente, deja de hacer el tonto.

'Honestly, stop making a fool of yourself.' 
prop $_{5}$ : honestamente 2 appears especially in embedded position (cf. examples 28-30 and 32) and it also appears frequently in initial position (cf. example 33) or final position (cf. example $31)$.

b) Semantic-pragmatic properties:

prop $_{6}$ : honestamente 2 can be paraphrased by Soy honesto al decir que $\mathrm{P}$ (where $\mathrm{P}$ assumes the content of the stated proposition).

prop $_{7}$ : the semantic structure of this operator is usually $\mathrm{p}$ honestamente $2 \mathrm{q}$, where $\mathrm{p}$ and $\mathrm{q}$ are in opposition to each other (cf. example 28: $\mathrm{p}=$ He recibido amenazas vs. $\mathrm{q}=$ No las tomo mиy en serio). This opposition may take place between actualized contents or virtually contents.

\subsubsection{Contrastive Analysis}

In the table below (cf. table 1) we have summarized the properties arising from a characterization of the French adverb honnêtement and the Spanish adverb honestamente:

\begin{tabular}{|c|c|c|c|c|c|c|}
\hline & \multicolumn{3}{|c|}{ HONNÊTEMENT } & \multicolumn{3}{|c|}{ HONESTAMENTE } \\
\hline & $\begin{array}{l}\text { honnête- } \\
\text { ment }_{1}\end{array}$ & $\begin{array}{l}\text { honnête- } \\
\text { ment }_{2}\end{array}$ & $\begin{array}{l}\text { honnête- } \\
\text { ment }_{3}\end{array}$ & $\begin{array}{l}\text { honesta- } \\
\text { mente }_{1}\end{array}$ & $\begin{array}{l}\text { honesta- } \\
\text { mente }_{\mathrm{x}}\end{array}$ & $\begin{array}{l}\text { honesta- } \\
\text { mente }_{2}\end{array}$ \\
\hline Adverb Type & $\begin{array}{l}\text { Adv of } \\
\text { manner }\end{array}$ & $\begin{array}{c}\text { Adv of } \\
\text { degree }\end{array}$ & $\begin{array}{c}\text { Statement } \\
\text { adverb }\end{array}$ & $\begin{array}{l}\text { Adv of } \\
\text { manner }\end{array}$ & $\begin{array}{c}\text { Adv of } \\
\text { degree }\end{array}$ & $\begin{array}{c}\text { Statement } \\
\text { adverb }\end{array}$ \\
\hline $\begin{array}{l}\text { Existence } \\
\text { Proven }\end{array}$ & $\sqrt{ }$ & $\sqrt{ }$ & $\sqrt{ }$ & $\sqrt{ }$ & - & $\sqrt{ }$ \\
\hline Frequency & $129 / 200$ & $15 / 200$ & $56 / 200$ & $167 / 200$ & - & $33 / 200$ \\
\hline $\begin{array}{l}\text { Surface } \\
\text { structure }\end{array}$ & $\mathrm{H}(\mathrm{X})$ & $\mathrm{H}(\mathrm{X})$ & $\mathrm{H}(\mathrm{X}, \mathrm{Y})$ & $\mathrm{H}(\mathrm{X})$ & - & $\mathrm{H}(\mathrm{X}, \mathrm{Y})$ \\
\hline Cleft & $\sqrt{ }$ & - & - & - & - & - \\
\hline $\begin{array}{l}\text { Initial detached } \\
\text { position }\end{array}$ & - & - & $\sqrt{ }$ & - & - & $\sqrt{ }$ \\
\hline $\begin{array}{l}\text { Focus of } \\
\text { negation }\end{array}$ & $\sqrt{ }$ & $\sqrt{ }$ & - & $\sqrt{ }$ & - & - \\
\hline $\begin{array}{l}\text { Stand-alone } \\
\text { response }\end{array}$ & $\sqrt{ }$ & - & - & $\sqrt{ }$ & - & - \\
\hline $\begin{array}{l}\text { At the head of } \\
\text { any sentence }\end{array}$ & - & - & $\sqrt{ }$ & - & - & $\sqrt{ }$ \\
\hline $\begin{array}{l}\text { Position of the } \\
\text { Adverb facing } \\
\text { the adjective/ } \\
\text { verb }\end{array}$ & Postposition & Preposition & - & Postpostion & - & - \\
\hline $\begin{array}{l}\text { Possibility of } \\
\text { degree } \\
\text { (superiority) }\end{array}$ & - & $\sqrt{ }$ & - & - & - & - \\
\hline $\begin{array}{l}\text { Possibility of } \\
\text { intensification } \\
(\text { et même) }\end{array}$ & $\sqrt{ }$ & $\sqrt{ }$ & - & $\sqrt{ }$ & - & - \\
\hline $\begin{array}{l}\text { Paraphrase of } \\
d(\text { 'une }) / d e \\
\text { manière/manera } \\
+ \text { Adj }\end{array}$ & $\sqrt{ }$ & - & - & $\sqrt{ }$ & - & - \\
\hline $\begin{array}{l}\text { Paraphrased by } \\
\text { the verb } \\
\text { faire/hacer }\end{array}$ & $\sqrt{ }$ & - & - & $\sqrt{ }$ & & - \\
\hline
\end{tabular}




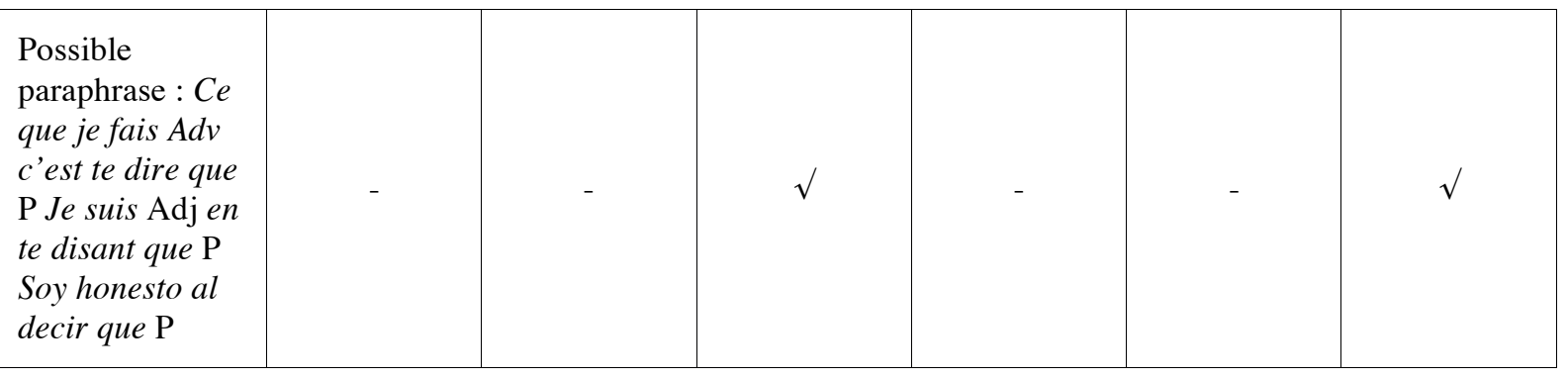

Table 1: Uses and properties of honnêtement and honestamente

As we have seen, the adverb honnêtement in French has three different uses (i.e. adverb of manner referring to the subject, adverb of degree and statement adverb) compared to only two for the adverb honestamente in Spanish (i. e. adverb of manner referring to the subject and statement adverb).

If we were to propose a gloss for the function of these adverbs in each of their uses, we could point out that in the first common use, when we state honnêtement /honestamente $_{1}(\mathrm{X})$, we characterize the fulfilment of the process stated by the verb in the statement: we specify the manner in which this process has been accomplished, namely, that it has been accomplished in an honest manner.

Regarding the frequency of this use, we can say that it is by far the most frequent function both in French (129 occurrences out of 200) and Spanish (167 occurrences out of 200 examples). Concerning their properties, we can see that they are similar in both languages, except for the fact that honestamente cannot be extracted by $C^{\prime}$ 'est... que, as cleft sentences are not a feature of Spanish.

Similarly, we can gloss the second common use (the use as a statement adverb), in the following way: when the speaker states honnêtement $3(\mathrm{X}, \mathrm{Y}) /$ honestamente $_{2}(\mathrm{X}, \mathrm{Y})$, he is qualifying a phrase containing a statement, to which he assigns the property of honesty. Again, the properties are similar in both languages; and the frequency of use is slightly higher in French (56 occurrences out of 200) than in Spanish (33 occurrences out of 200).

Unlike Spanish though, the French adverb honnêtement has a third function: it can be used as an adverb of degree or intensity. In this case, when the speaker states honnêtement ${ }_{2}(\mathrm{X})$, he is expressing an average or slightly above average degree of intensity with regard to the content of the adjective modified by honnêtement. While there are few cases (some 15 examples out of 200), it seems that the pre-position of the adverb in relation to the adjective it modifies plays an essential role, as, were it to be in postposition, it would have the function of an adverb of manner (thus honnêtement ${ }_{1}$ ).

\section{$3 \quad$ Sérieusement vs. seriamentelen serio}

Our next study is concerned with the adverbs sérieusement in French and seriamente and en serio in Spanish (since we have observed that the uses of sérieusement admit, depending on the context, two possible translations into Spanish: seriamente and en serio). Having applied the same tests as with the preceding adverbs, we have detected three uses for the adverb sérieusement and only two uses for each of the Spanish adverbs (i.e. seriamente and en serio). 
These three uses we have found are the following:

i. A manner adverb referring to the subject, which characterizes the fulfilment of the process stated by the verb in the statement:

Tu parles sérieusement?

'Are you speaking seriously?'

Australia es muy grande, tiene un tamaño muy superior al de las islas Canarias y, sin embargo, los australianos se plantean seriamente erradicar los gatos de su mundo.

'Australia is vast - much bigger than the Canary Islands. However, Australians are seriously thinking of eradicating cats from their country.'

Y vivirás en serio tu catolicismo.

'And you will experience Catholicism seriously.'

ii. An adverb of degree or intensity, which indicates a high degree of content with regard to the adjective or verb being modified:

Le PSG énerve sérieusement Guy Roux.

'PSG seriously annoys Guy Roux.'

Grandes extensiones de bosques centroeuropeos, especialmente de coníferas, están seriamente afectadas por esta contaminación.

'Large extension of Central European forests, especially conifers, are seriously being affected by this pollution.'

iii. Finally, a statement adverb showing the speaker's attitude towards his own statement:

En Jamaïque, "tu ne peux rien acheter avec 1 dollar, sérieusement", s'exclame sur Twitter Laura Edwards.

'In Jamaica, 'you can't buy anything with one dollar - seriously', Laura Edwards exclaimed on Twitter.'

Mientras no cambies, en serio, ni serás feliz, ni conseguirás la paz que anhelas.

'If you don't change, seriously, you will neither be happy nor will you find the peace you long for.'

As shown above, we have identified three functions of the French adverb sérieusement; on the other hand, in the case of Spanish, while seriamente and en serio both have uses as adverbs of manner, there are differences between them regarding their second use: seriamente functions as an adverb of degree or intensity (it does not exist as a statement adverb), whereas en serio functions as a statement adverb (it does not exist as an adverb of degree).

We shall consider in detail the characteristics of each of these uses.

\section{1 sérieusement}

\subsection{1 sérieusement}

An initial function of the French adverb sérieusement is that of a constituent adverb, analogous with the use of honnêtement ${ }_{1}$. 
We shall consider some examples from our corpus:

37. Tu parles sérieusement? (Delteil, 2009).

'Are you speaking seriously?'

38. Alexandre la considéra sérieusement (Pancol, 2006).

'Alexandre seriously considered her'

39. Marc, qui n'était pas de mauvaise foi, réfléchit sérieusement à cette phrase (Vargas, 2000).

'Marc, who wasn't being insincere, seriously reflected on this sentence'

40. Trois quarts d'heure plus tard, j'ai fini de lire Le Canard enchaîné, bouclé le dernier Douglas Kennedy et je songe sérieusement à décliner mon identité afin de faire accélérer les choses (Shepard, 2011).

'Three quarters of an hour later, I have finished reading Le Canard enchaîné, ended the last book by Douglas Kennedy and I am seriously dreaming of giving up my identity in order to speed things up'

41. Et peut-on vraiment affirmer sérieusement que ça n'empêche pas d'acheter des disques? (Nègre, 2010).

'And can we really seriously state that this does not prevent people from buying records and CDs?'

We believe it functions as an adverb of manner, since it displays the same linguistic properties settled before for honnêtement 1 :

a) Syntactic properties:

prop $_{1}$ : sérieusement 1 has a surface structure $\mathrm{S}(\mathrm{X})$, where $\mathrm{S}$ stands for sérieusement and $\mathrm{X}$ for the predicate it modifies.

prop $_{2}$ : sérieusement 1 can be extracted in a cleft sentence:

37a. C'est sérieusement que tu parles?

38a. C'est sérieusement qu'Alexandre la considéra.

39a. C'est sérieusement que Marc réfléchit à cette phrase.

prop $_{3}$ : it can be the focus of the negation:

37b. Tu parles mais tu ne parles pas sérieusement.

38b. Il la considéra mais il ne la considéra pas sérieusement.

39b. Marc réfléchit à cette phrase, mais il ne réfléchit pas sérieusement.

prop $_{4}$ : it can stand alone as a response:

42. Comment s'est-il comporté? Sérieusement.

'How has he behaved himself? Seriously.'

b) Semantic-pragmatic properties: 
prop $_{5}$ : sérieusement ${ }_{1}$ always modifies the verb and can be paraphrased by de (d'une) manièrelfaçon + Adj (sérieuse):

37c. Tu parles de façon sérieuse.

38c. Alexandre la considéra de façon sérieuse.

39c. Marc réfléchit à cette phrase de manière sérieuse.

prop $_{6}$ : sérieusement 1 belongs to a group of adverbs that establish a relationship between a verb and a noun phrase, acting as an agent. It appears in this way with agent verbs and where another possible paraphrase is the verb faire (Schlyter 1977):

37e. Tu le fais [= parler] sérieusement?

38e. Alexandre le fait [= la considérer] sérieusement.

39e. Marc, qui n'était pas de mauvaise foi, le fait [= réfléchir à cette phrase] sérieusement.

\subsection{2 sérieusement ${ }_{2}$}

As with honnêtement, the second function of the adverb sérieusement is that of an adverb of degree, with an analogous use of honnetement $t_{2}$.

Here are a few examples from our corpus:

43. Le PSG énerve sérieusement Guy Roux (Le PSG énerve sérieusement Guy Roux, [14.10.2018]).

'PSG seriously annoys Guy Roux]

44. Il n'était pas surprenant de voir l'hémicycle sérieusement clairsemé lors de la séance de lundi soir (Bekmezian, 2013).

'It wasn't surprising to see the serious sparse attendance in the National Assembly during the Monday evening session'

45. Oui. La voiture rouge avait changé de place. Alexandra a dû rétracter sa première déclaration, elle s'est fait sérieusement engueuler et a avoué s'être absentée de onze heures un quart à trois heures du matin (Vargas, 2000).

'Yes. The red car wasn't parked in the same place. Alexandra had to withdraw her first statement, and got a serious talking-to. Then she admitted that she had been out between quarter past eleven last night and three in the morning'

46. Le silence à l'autre bout de la ligne m'indique que mon argument a fait mouche. Il est certains mots magiques à la mairie. Dire qu'on prévient le maire de l'inaction de ses services se classe en tête de la liste. Son éventuelle ire face à la paresse de ses services relève de la légende administrative, puisqu'il a lui-même installé la plupart des pires glandeurs de la mairie au sommet de l'organigramme, mais elle semble ébranler sérieusement la secrétaire de Barbara qui se met à bredouiller :

- Je ne peux pas quitter mon poste pour vous l'apporter (Shepard, 2011).

'The silence at the other end of the line shows me that my argument has been successful. There are certain magic words at the town hall. To prevent the mayor from not performing his duties is at the top of list. His possible anger due to the laziness of 
his duties helps to increase the administrative myth since he has made himself one of laziest people at the top of the organization chart. But this seems to seriously trouble Barbara's secretary who begins to mumble:

- I cannot leave my post so you can have it'

47. Il paraît pourtant qu'il a sérieusement importuné Noémie Labarrière (Aubert, 2006).

'Therefore, it seems that he has seriously annoyed Noémie Labarrière'

We shall consider the linguistic properties of this second use (properties similar to those identified for honnêtement $t_{2}$ ).

a) Syntactic properties:

prop $_{1}$ : sérieusement 2 has a surface structure $\mathrm{S}(\mathrm{X})$.

prop $_{2}$ : sérieusement ${ }_{2}$ cannot be located at the head of a sentence:

43a. * Sérieusement le PSG énerve Guy Roux.

44a. * Sérieusement il n'était pas surprenant de voir l'hémicycle clairsemé lors de la séance de lundi soir.

45a. * Sérieusement elle s'est fait engueuler.

prop $_{3}$ : sérieusement 2 can be the focus of negation:

43b. Le PSG énerve Guy Roux, mais il ne l'énerve pas sérieusement.

44b. L’hémicycle était clairsemé, mais il n'était pas sérieusement clairsemé.

45b. Elle s'est fait engueuler, mais elle ne s'est pas fait sérieusement engueuler.

prop $_{4}$ : sérieusement 2 appears in front of the adjective or verb form that it modifies (cf. examples 44-45 and 47), or more rarely, after the verb form it is dealing with (cf. examples 43 and 46).

The position of sérieusement in the statement is a key element especially when it modifies an adjective (or past participle), as if it is in final position (non-detached), it would be interpreted as an adverb of manner referring to the subject (hence sérieusement ${ }_{1}$ ): Il l'a sérieusement devancé dans la course (= adverb of degree) vs. Il l'a devancé sérieusement (= adverb of manner).

b) Semantic-pragmatic properties:

prop $_{5}$ : sérieusement 2 can be sometimes paraphrased by Le $\mathrm{N}$ est Adj (a paraphrase that excludes sérieusement ${ }_{1}$ and sérieusement ${ }_{3}$ ):

43d. L'énervement de Guy Roux est sérieux.

45d. Son engueulade est sérieuse.

prop $_{6}$ : in contemporary French argot it can be substituted by the adjective grave:

43e. Le PSG énerve grave Guy Roux.

45e. Elle s'est fait grave engueuler. 
prop $_{7}$ : sérieusement 2 - unlike what we have observed in the case of sérieusement 1 - always refers to verbs or adjectives which stem from a rather negative consequence if we exceed a certain degree or intensity (i. e. énerver, importuner, ébranler, chauffer, clairsemer, etc.).

prop $_{8}$ : it does not seem difficult to find the semantic value of degree or intensity from this sérieusement $_{2}$ in the meaning of the adverb itself on which it is built (i.e. sérieux/sérieuse). Indeed, the Trésor de la Langue Française informatisé (http://stella.atilf.fr) offers the following three definitions for the adjective sérieux/sérieuse when applied to things which:

1. Deserve to be taken into account owing to their importance.

2. Count in terms of their intensity, their qualitative or quantitative importance, size or importance.

3. Deal with an important subject.

We can observe that the degree or intensity value is already present in the second meaning of this definition. ${ }^{1}$

\subsection{3 sérieusement $_{3}$}

The third use of sérieusement in French is that of a sentence adverb, or more precisely a statement adverb. Below are a few examples:

48. Je flambe! Sérieusement, je dois récupérer la quarantaine de Chinois qui se sont échappés dans votre casino, pour leur faire boire du vin et caresser des vaches. (Shepard, 2011).

'I gamble large sums of money! Seriously, I must find the forty something Chinese men who escaped from your casino, to make them drink wine and stroke cows.'

49. Non... Sérieusement, d'après nos constatations, vers les cinq heures du mat', reprit-il, tout ce petit monde est fatigué après une longue nuit de labeur. Alors ça roupille, la vigilance se relâche. C'est le moment idéal pour la percée (Jonquet, 2007).

'No... Seriously, we found that at about five in the morning, he went on, they are all tired after a hard night's labor. When they fall asleep, the vigilance is relaxed. It's the ideal moment to break in'

50. En Jamaïque, "tu ne peux rien acheter avec 1 dollar, sérieusement", s'exclame Laura Edwards sur Twitter (Duretz, 2013).

'In Jamaica, "you can't buy anything with one dollar - seriously", Laura Edwards exclaimed on Twitter'

51. Rempart contre l'islamisme, sérieusement, le régime qui a, pendant presque quinze ans, hébergé le bureau politique du Hamas, branche palestinienne des Frères musulmans et fer de lance, à ce titre, d'une des formes les plus radicales du fondamentalisme? Rempart contre l'islamisme? (Henry-Levy, 2017).

\footnotetext{
${ }^{1}$ Regarding the question whether the adverbs have the same semantic properties of the adjectives they derive from, we shall quote Rodríguez Ramalle (2003) who says that "Considero que el hecho de que un adverbio en mente denote valores tan diferentes no es simplemente un problema de productividad del sufijo [...], sino que tiene que ver con que -mente carece de valor semántico propio; por lo que sus rasgos semánticos vienen determinados por el adjetivo" (Rodríguez Ramalle 2003: 17).
} 
'A shield against Islamism, seriously, the regime that for almost fifteen years has hosted the political office of Hamas, the Palestinian branch of the Muslim Brotherhood and its driving force, therefore, one of the most radical forms of fundamentalism? A shield against Islamism?'

52. Un texte sur la disparition des bureaux de poste dans les campagnes françaises? Sérieusement? Jean-Pierre Pernaut avait-il pris possession de votre esprit au moment du choix des sujets?! (Shepard, 2011).

'A text about the disappearance of post offices in the French countryside? Seriously? Had Jean-Pierre Pernaut taken possession of your spirit when choosing the topics?!'

Regarding the linguistic properties that characterize this use, we find that they are similar to those of honnêtement ${ }_{3}$ seen above:

a) Syntactic properties:

prop $_{1}$ : sérieusement 3 has a surface structure $\mathrm{S}(\mathrm{X}, \mathrm{Y})$, whose standard form would be of the type $\mathrm{X}$ sérieusement ${ }_{3} \mathrm{Y}$.

prop $_{2}$ : sérieusement 3 can appear in detached position at the head of a negative sentence:

48a. Sérieusement, je ne dois pas récupérer la quarantaine de Chinois qui se sont échappés dans votre casino.

49a. Sérieusement, d'après nos constatations, vers les cinq heures du mat', reprit-il, tout ce petit monde n'est pas fatigué après une longue nuit de labeur.

50a. Sérieusement, en Jamaïque tu ne peux rien acheter avec 1 dollar.

prop $_{3}$ : sérieusement 3 cannot be extracted by C'est ... que.

48b. * C'est sérieusement que je dois récupérer la quarantaine de Chinois qui se sont échappés dans votre casino.

49b. * C'est sérieusement, d'après nos constatations, que vers les cinq heures du mat', reprit-il, tout ce petit monde est fatigué après une longue nuit de labeur

50b. * C'est sérieusement qu'en Jamaïque tu ne peux rien acheter avec 1 dollar.

prop $_{4}$ : sérieusement 3 cannot be the focus of negation:

48c. * Je dois récupérer la quarantaine de Chinois qui se sont échappés dans votre casino, mais je ne dois pas les récupérer sérieusement.

49c. * D'après nos constatations, vers les cinq heures du mat', reprit-il, tout ce petit monde est fatigué après une longue nuit de labeur, mais il n'est pas fatigué sérieusement.

50c. * En Jamaïque tu peux acheter quelque chose avec un dollar, mais tu ne peux pas l'acheter sérieusement.

prop $_{5}$ : it can appear at the head of any type of sentence: declarative affirmative (cf. examples 48 and 49) negative (cf. example 53), interrogative (cf. example 51) and even imperative (cf. example 54). 
51d. Sérieusement, rempart contre l'islamisme le régime qui a, pendant presque quinze ans, hébergé le bureau politique du Hamas, branche palestinienne des Frères musulmans et fer de lance, à ce titre, d'une des formes les plus radicales du fondamentalisme?

53. Sérieusement, en Jamaïque tu ne peux rien acheter avec 1 dollar.

54. Sérieusement, laisse tomber (oral).

'Seriously - forget it'

prop $_{6}$ : sérieusement 3 appears especially at the head of a sentence (in initial front detached position, cf. examples 48 and 49) and often appears in final position (cf. example 50) or embedded (cf. example 51).

b) Semantic-pragmatic properties:

prop $_{7}$ : sérieusement 3 can be paraphrased by Ce que je fais sérieusement c'est te dire que $\mathrm{P}$ or Je suis sérieux en te disant que $\mathrm{P}$ (where $\mathrm{P}$ assimilates the content of the stated proposition).

48e. Ce que je fais sérieusement c'est te dire que je dois récupérer la quarantaine de Chinois qui se sont échappés dans votre casino.

48f. Je suis sérieux en te disant / lorsque je te dis que je dois récupérer la quarantaine de Chinois qui se sont échappés dans votre casino.

50e. Ce que je fais sérieusement c'est te dire qu'en Jamaïque tu ne peux rien acheter avec 1 dollar.

50f. Je suis sérieux en te disant / lorsque je te dis qu'en Jamaïque tu ne peux rien acheter avec 1 dollar.

Having considered sérieusement, we shall now turn to the Spanish adverbs seriamente and en serio.

\section{2 $\quad$ seriamente}

Having submitted examples from our corpus to the linguistic tests mentioned above, we have found two different uses for seriamente: a primary use as an adverb of manner referring to the subject and a secondary use as an adverb of degree or intensity.

\subsection{1 seriamente $_{1}$}

The first use we have identified for the adverb seriamente is that of an adverb of manner referring to the subject, analogous with honestamente ${ }_{1}$.

We shall consider a few examples taken from the CREA corpus:

55. Australia es muy grande, tiene un tamaño muy superior al de las islas Canarias y, sin embargo, los australianos se plantean seriamente erradicar los gatos de su mundo.

'Australia is vast - much bigger than the Canary Islands. However, Australians are seriously thinking of eradicating cats from their country.'

56. Los grupos enemigos y sus jefes suelen ser percibidos como tan perversos y mal intencionados que no vale la pena negociar seriamente con ellos, o bien se les cree tan 
débiles o estúpidos que se considera que todo esfuerzo para conciliar las diferencias estará destinado al fracaso.

'The enemies and their bosses are usually considered as either being so perverse and malicious that it isn't seriously worth negotiating with them or so weak or stupid that any effort aimed at reconciling their differences will end up in failure.'

57. A principios de la década de los años 60, diversos organismos internacionales empezaron a preocuparse seriamente del asunto y la FAO (Organización de las Naciones Unidas para la Agricultura y la Alimentación) convocó una reunión de la cual surgió un Cuadro de Expertos en Prospección de Plantas.

'In the early 1960 s, several international organizations started to seriously worry about the issue and FAO (Food and Agriculture Organization of the United Nations) set up a meeting in which a Panel of Experts on Plant Exploration and Introduction emerged.'

58. Hace unos años, Margulis tuvo la feliz idea de plantear seriamente que uno de los motores de la evolución es la simbiosis entre especies que se encuentran en contacto.

'A few years ago, Margulis had the bright idea of seriously considering that symbiosis between species that are in contact is one of the driving forces of evolution.'

59. Allí se dañó seriamente la muñeca derecha durante un duelo; una forma de pasar el tiempo muy prusiana.

'There he seriously injured his wrist during a duel - a strictly disciplined way of spending time.'

The following are the linguistic properties of this use of seriamente:

a) Syntactic properties:

prop $_{1}$ : $_{\text {seriamente }}$ has a surface structure $\mathrm{S}(\mathrm{X})$.

prop $_{2}$ : it cannot appear at the head of a sentence:

55a. * Seriamente los australianos se plantean erradicar los gatos de su mundo.

56a. * Seriamente no vale la pena negociar con ellos.

57a. * Seriamente diversos organismos internacionales empezaron a preocuparse del asunto.

prop $_{3}$ : it can appear alongside a negative statement:

55b. Los australianos se plantean erradicar los gatos de su mundo, pero no se lo plantean seriamente.

56b. Vale la pena negociar con ellos, pero no vale la pena negociar seriamente.

57b. Diversos organismos internacionales empezaron a preocuparse del asunto, pero no empezaron a preocuparse seriamente.

prop $_{4}$ : it can stand alone as a response, qualifying the manner in which the action is fulfilled:

60. ¿LLlegó a plantearse seriamente encabezar la lista?

- Sí. Seriamente. Era mi obligación reflexionarlo en profundidad, y lo hice.

- Did you seriously consider heading the list? -Yes. Seriously. It was my duty to reflect on it carefully, which I did.' 
b) Semantic-pragmatic properties:

prop $_{5}$ : seriamente $_{1}$ always modifies the verb and can be paraphrased by de maneralforma + Adj (serialgrave):

55c. Los australianos se plantean erradicar los gatos de su mundo de manera seria.

56c. Vale la pena negociar con ellos de forma seria.

57c. Diversos organismos internacionales empezaron a preocuparse del asunto de forma seria.

prop $_{6}$ : seriamente ${ }_{1}$ belongs to a group of adverbs that establish a relationship between a verb and a noun phrase acting as an agent. It appears in this way with agent verbs and can be paraphrased by the verb hacer:

55d. Lo hacen [= plantearse algo] seriamente.

57d. Diversos organismos internacionales lo hicieron [= empezar a preocuparse del asunto] seriamente.

\subsection{2 seriamente $_{2}$}

As with sérieusement but unlike honestamente, the second use of the adverb seriamente is that of an adverb of degree. Here are a few examples from our corpus (CREA):

61. Grandes extensiones de bosques centroeuropeos, especialmente de coníferas, están seriamente afectadas por esta contaminación.

'Large extension of Central European forests, especially conifers, are seriously being affected by this pollution.'

62. En Escandinavia, por ejemplo, se afirma que el bosque boreal se encuentra seriamente amenazado por las precipitaciones ácidas y que las pesquerías se encuentran asimismo afectadas por los contaminantes atmosféricos.

'In Scandinavia, for example, it is stated that boreal forests are seriously being threatened by acid rain and that fishing grounds are also being affected by atmospheric pollutants.'

63. Además de estar seriamente enferma, había recibido un tiro en la espalda.

'Besides being seriously ill, she had been shot in the back.'

64. Si en un principio, es decir, en la década de 1950 y primeros años de la de 1960, la construcción de centrales nucleares apenas era contestada públicamente -era la época de los llamados "átomos para la paz"-, fue luego encontrando mayores oposiciones y muchos planes nucleares de algunos países se vieron seriamente afectados por el celo y el entusiasmo de los grupos antinucleares y de ciertas capas de la sociedad más o menos amplias. Los problemas energéticos, en efecto, no sólo son de naturaleza técnica sino también social y política.

'At first, that is, in the 1950s and the beginning of the 1960s, the building of nuclear power plants was hardly disapproved in public - it was the time of the famous 'Atoms for Peace' speech. However, it later faced more opposition and many nuclear plans of some countries were seriously affected by the passion and enthusiasm of anti-nuclear 
groups and certain levels of society to a greater or lesser extent. Problems with energy are indeed not only technical but also social and political.'

65. En la actualidad este modelo lineal de la innovación tecnológica está seriamente cuestionado.

'This linear model of technological innovation is currently being seriously questioned.'

We shall consider the linguistic properties of this second use:

a) Syntactic properties:

prop $_{1}$ : seriamente $_{2}$ has a surface structure $\mathrm{S}(\mathrm{X})$.

prop $_{2}$ : seriamente 2 cannot go at the head of a sentence:

61a. * Seriamente grandes extensiones de bosques centroeuropeos, especialmente de coníferas, están afectadas por esta contaminación.

62a. * Seriamente en Escandinavia, por ejemplo, se afirma que el bosque boreal se encuentra amenazado por las precipitaciones ácidas y que las pesquerías se encuentran asimismo afectadas por los contaminantes atmosféricos.

63a. * Seriamente además de estar enferma, había recibido un tiro en la espalda.

prop $_{3}:$ seriamente $_{2}$ can be the focus of a negation:

61b. Grandes extensiones de bosques centroeuropeos, especialmente de coníferas, están afectadas por esta contaminación, pero no están afectadas seriamente.

62b. En Escandinavia, por ejemplo, se afirma que el bosque boreal se encuentra amenazado por las precipitaciones ácidas y que las pesquerías se encuentran asimismo afectadas por los contaminantes atmosféricos, pero no se encuentran amenazadas seriamente.

63b. Está enferma, pero no seriamente.

prop $_{4}$ : seriamente 2 appears in front of the adjective form that it modifies.

b) Semantic-pragmatic properties:

prop $_{5}$ : seriamente $_{2}$ can be paraphrased by $E l \mathrm{~N}$ es Adj:

62d. La amenaza es seria.

63d. La enfermedad es seria.

prop $_{6}:$ seriamente $_{2}$ is always focused on adjectives which are the source of rather negative consequences when they exceed a certain degree or a certain intensity (i.e. afectado, amenazado, enfermo, cuestionado, etc.).

prop $_{7}$ : it is easy to identify the semantic value of degree or intensity from this seriamente 2 in the meaning of the adjective upon which it is built (i.e. serio/a). We can find the following definition in Diccionario de la Real Academia de la Lengua Española (DRAE):

Definition DRAE (cf. http://dle.rae.es) serio, ria: 
Del lat. serius.

1. adj. Grave, sentado y compuesto en las acciones y en el modo de proceder.

2. adj. Dicho de una acción: Propia de una persona seria.

3. adj. Severo en el semblante, en el modo de mirar o hablar.

4. adj. Real, verdadero y sincero, sin engaño o burla, doblez o disimulo.

5. adj. Grave, importante, de consideración. Negocio serio. Enfermedad seria.

6. adj. U. contrapuesto a jocoso o bufo. Ópera seria.

We can see from this that the value of degree or intensity is already present in the fifth meaning (cf. 5. adj. Grave, importante, de consideración. Negocio serio. Enfermedad seria).

\subsection{3 seriamente $_{\mathrm{x}}$}

We have found no examples of seriamente as a statement adverb.

\section{3 en serio}

Finally, we shall examine the adverbial phrase en serio, which could be an acceptable translation into Spanish of certain uses of the French adverb sérieusement. Indeed, we have found two uses for en serio: one as an adverb of manner referring to the subject and the other as a sentence adverb, or more accurately as an enunciative adverb.

\subsection{1 en serio}

A first use of the phrase en serio is that of a component adverb or adverb of manner referring to the subject, similar to the use of sérieusement ${ }_{1}$ :

Here are a few examples from our corpus - taken from CREA:

66. Los economistas liberales pronto le [sic] tomaron en serio.

'Liberal economists soon took him seriously.'

67. Por vez primera me acercaba en serio al dominio de las ciencias de la naturaleza.

'For the first time I was approaching natural science seriously.'

68. Y vivirás en serio el catolicismo.

'And you will experience Catholicism seriously.'

69. Unos se entregarán, otros se tomarán en serio su vida interior.

'Some will be devoted; others will take their interior life seriously.'

70. Este se comenzó a cuestionar muy en serio la posibilidad de un crecimiento indefinido. 'He started to very seriously question the possibility of indefinite growth.'

This use has the following linguistic properties:

a) Syntactic properties:

prop $_{1}$ : en serio $_{1}$ has the surface structure ES (X).

prop $_{2}$ : en serio 1 it cannot go in detached position at the head of a negative sentence: 
66a. * En serio los economistas liberales pronto no le [sic] tomaron.

67a. * En serio por vez primera no me acercaba al dominio de las ciencias de la naturaleza.

68a. * En serio no vivirás el catolicismo.

prop $_{3}$ : it can be stand alongside a negative statement:

67b. Por vez primera me acercaba al dominio de las ciencias de la naturaleza, pero no me acercaba en serio.

68b. Vivirás el catolicismo, pero no lo vivirás en serio.

prop $_{4}$ : it can stand alone as a response:

71. ¿Cómo se debe tomar el asunto? En serio.

'How should the matter be taken into account? Seriously.'

b) Semantic-pragmatic properties:

prop $_{5}$ : en serio ${ }_{1}$ modifies the verb and can be paraphrased by de manera / forma + Adj (seria / grave):

66c. Los economistas liberales pronto le [sic] tomaron de forma seria.

67c. Por vez primera me acercaba de manera seria al dominio de las ciencias de la naturaleza 68c. Y vivirás de forma seria el catolicismo.

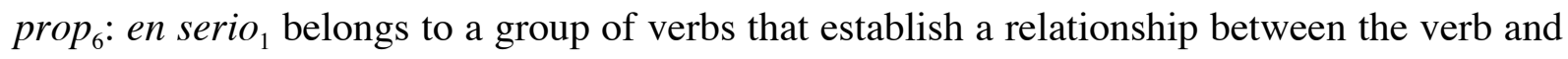
the noun phrase acting as agent. It appears like this with agent verbs and can be paraphrased by the verb hacer:

66d. Los economistas liberales pronto lo hicieron en serio.

67d. Por vez primera lo hacía en serio al dominio de las ciencias de la naturaleza

68d. Y lo harás en serio el catolicismo.

\subsection{2 en serio $_{\mathrm{x}}$}

We have found no examples where en serio functions as an adverb of degree or intensity.

\subsection{3 en serio $_{3}$}

We can now turn to the second and last use of the adverb in question: the use of en serio as a sentence adverb, or more accurately as an enunciative adverb.

Here are a few examples - taken from CREA unless otherwise stated:

72. Mientras no cambies, en serio, ni serás feliz, ni conseguirás la paz que anhelas. 'If you don't change, seriously, you will neither be happy nor will you find the peace you long for.'

73. Bueno, bueno, ahora en serio -puntualiza una tercera-: está quedando pero... 'Well, well, now seriously - points out a third: it is looking good, but...' 
74. Ya más en serio, no estaría mal que recuperáramos ese verdadero...

'Now more seriously, it wouldn't be a bad idea to recover that true ...'

75. Este supermercado solo vende productos vencidos (en serio) (http://www.crhoy.com/ambiente/este-supermercado-solo-vende-productos-vencidosen-serio/, 2016).

'This supermarket only sells expired products (seriously)'

76. Bueno bueno, pero por circunstancias que no vienen al caso. Eso. Y y además yo estaba enfermo. Ya. Estaba enfermo y, bueno, los otros no quieras saber, los otros compañeros. Sí, sí. Estaba malísimo, en serio. Ya, sí hombre, ya. Malísimo.

'Well, well, but because of irrelevant circunstances. That's right. And besides I was ill. Yes. I was ill and, well, you don't want to know about the other colleagues. Yes, indeed. He was really ill, seriously. Yes, of course, I see. Really ill.'

Below are the linguistic properties characterizing this use:

a) Syntactic properties:

prop $_{1}$ : en serio $_{2}$ has a surface structure ES (X, Y), whose standard version would be of the type $\mathrm{X}$ en serio $_{2} \mathrm{Y}$.

prop $_{2}$ : en serio $_{2}$ can appear in detached position at the head of a negative sentence:

72a. En serio, ni serás feliz, ni conseguirás la paz que anhelas.

74a. En serio, no estaría mal que recuperáramos ese verdadero...

prop $_{3}$ : en serio 2 cannot be the focus of a negation:

72b. * Serás feliz y conseguirás la paz que anhelas, pero no lo serás en serio.

73b. * Está quedando pero no está quedando en serio.

74b. * Estaría mal que recuperáramos ese verdadero, pero no estaría mal en serio.

prop $_{4}$ : it can appear at the head of any type of sentence: declarative affirmative (cf. examples 73) and negative (cf. example 72 and 74), interrogative (cf. example 77) and even imperative (cf. example 78).

73c. En serio - puntualiza una tercera-: está quedando pero...

77. ¿En serio, vas a ir?

'Seriously, are you going?'

78. En serio, olvídalo.

'Seriously - forget it.'

prop $_{5}$ : en serio $_{2}$ is especially common in embedded position (cf. examples 72-74) and appears frequently in final position (detached, cf. examples 75 and 76) and can appear in initial detached position (cf. examples 72 and 74).

b) Semantic-pragmatic properties:

prop $_{6}$ : en serio $_{2}$ can be paraphrased by Soy serio al decir que $\mathrm{P}$ (where $\mathrm{P}$ assimilates the content of the stated proposition). 
72d. Soy serio al decir que mientras no cambies, ni serás feliz, ni conseguirás la paz que anhelas.

73d. Soy serio al decir que no estaría mal que recuperáramos ese verdadero...

\subsection{Constrastive Analysis}

In the table below (cf. table 2) we shall review the uses and properties of the adverbs sérieusement, seriamente and en serio that we have analyzed previously:

\begin{tabular}{|c|c|c|c|c|c|c|c|c|c|}
\hline & SÉK & EUSEMI & & & RIAME & & & V SERI & \\
\hline & sér ${ }_{1}$ & sér $_{2}$ & sér $r_{3}$ & ser $_{1}$ & $\mathrm{ser}_{2}$ & $\operatorname{ser}_{\mathrm{x}}$ & $e s_{1}$ & $e s_{\mathrm{X}}$ & $e s_{2}$ \\
\hline $\begin{array}{l}\text { Adverb } \\
\text { Type }\end{array}$ & $\begin{array}{l}\text { Adv of } \\
\text { manner }\end{array}$ & $\begin{array}{l}\text { Adv of } \\
\text { degree }\end{array}$ & $\begin{array}{l}\text { Stateme } \\
\text { nt } \\
\text { Adverb }\end{array}$ & $\begin{array}{l}\text { Adv of } \\
\text { manner }\end{array}$ & $\begin{array}{l}\text { Adv of } \\
\text { degree }\end{array}$ & $\begin{array}{l}\text { Statement } \\
\text { Adv. }\end{array}$ & $\begin{array}{l}\text { Adv of } \\
\text { manne } \\
r\end{array}$ & $\begin{array}{l}\text { Adv } \\
\text { of } \\
\text { degre } \\
\text { e }\end{array}$ & $\begin{array}{l}\text { Statem } \\
\text { ent } \\
\text { Adver } \\
\text { b }\end{array}$ \\
\hline $\begin{array}{l}\text { Existence } \\
\text { Proven }\end{array}$ & $\sqrt{ }$ & $\sqrt{ }$ & $\sqrt{ }$ & $\sqrt{ }$ & $\sqrt{ }$ & - & $\sqrt{ }$ & - & $\sqrt{ }$ \\
\hline $\begin{array}{l}\text { Frequency } \\
\text { of use }\end{array}$ & $103 / 200$ & $43 / 200$ & $54 / 200$ & $156 / 200$ & $44 / 200$ & - & $\begin{array}{c}300 / 32 \\
8 \\
\end{array}$ & - & $28 / 328$ \\
\hline $\begin{array}{l}\text { Surface } \\
\text { structure }\end{array}$ & $S(X)$ & $S(X)$ & $\begin{array}{c}\text { S (X, } \\
\text { Y) }\end{array}$ & $S(X)$ & $S(X)$ & - & ES (X) & - & $\begin{array}{c}\text { ES (X, } \\
Y)\end{array}$ \\
\hline Embedded & $\sqrt{ }$ & - & - & - & - & - & - & - & - \\
\hline $\begin{array}{l}\text { Initial } \\
\text { detached } \\
\text { position }\end{array}$ & - & - & $\sqrt{ }$ & - & - & - & - & - & $\sqrt{ }$ \\
\hline $\begin{array}{l}\text { Focus of } \\
\text { negation }\end{array}$ & $\sqrt{ }$ & - & - & $\sqrt{ }$ & - & - & $\sqrt{ }$ & - & - \\
\hline $\begin{array}{l}\text { Stand-alone } \\
\text { response }\end{array}$ & $\sqrt{ }$ & - & - & $\sqrt{ }$ & - & - & $\sqrt{ }$ & - & - \\
\hline $\begin{array}{l}\text { Head of } \\
\text { any type of } \\
\text { sentence }\end{array}$ & - & - & $\sqrt{ }$ & - & - & - & - & - & $\sqrt{ }$ \\
\hline $\begin{array}{l}\text { Position } \\
\text { Adv in } \\
\text { relation to } \\
\text { adjective/ve } \\
\text { rb }\end{array}$ & $\begin{array}{c}\text { Postposit } \\
\text { ed }\end{array}$ & $\begin{array}{l}\text { Prepos } \\
\text { ed }\end{array}$ & - & $\begin{array}{l}\text { Postposit } \\
\text { ed }\end{array}$ & $\begin{array}{l}\text { Prepos } \\
\text { ed }\end{array}$ & - & $\begin{array}{l}\text { Postpo } \\
\text { sited }\end{array}$ & - & - \\
\hline $\begin{array}{l}\text { Possibility } \\
\text { of degree } \\
\text { (superiority } \\
\text { ) }\end{array}$ & - & $\sqrt{ }$ & - & - & $\sqrt{ }$ & - & - & - & - \\
\hline $\begin{array}{l}\text { Possibility } \\
\text { of } \\
\text { intensificati } \\
\text { on }\end{array}$ & $\sqrt{ }$ & $\sqrt{ }$ & - & $\sqrt{ }$ & $\sqrt{ }$ & - & $\sqrt{ }$ & - & - \\
\hline $\begin{array}{l}\text { Paraphrase } \\
\text { of (d'une) } \\
\text { manière / } \\
\text { façon + Adj }\end{array}$ & $\sqrt{ }$ & - & - & $\sqrt{ }$ & - & - & $\sqrt{ }$ & - & - \\
\hline $\begin{array}{l}\text { Paraphrase } \\
\text { by verb } \\
\text { faire/hacer }\end{array}$ & $\sqrt{ }$ & - & - & $\sqrt{ }$ & - & - & $\sqrt{ }$ & - & - \\
\hline $\begin{array}{l}\text { Paraphrase } \\
\text { by Le N est } \\
\text { Adj / } \\
\text { El N es Adj }\end{array}$ & - & $\sqrt{ }$ & - & - & $\sqrt{ }$ & - & - & - & - \\
\hline
\end{tabular}




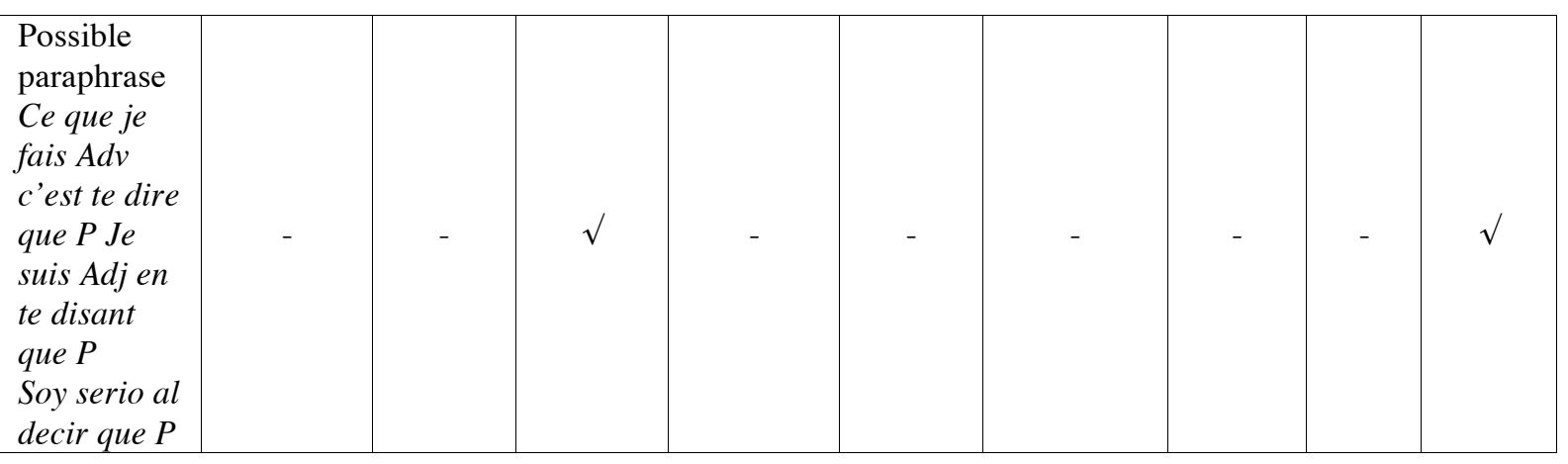

Table 2: Uses and properties of sérieusement, seriamente and en serio

From the above table, we can see that the French adverb sérieusement has three different uses, with distinct properties, while the Spanish adverbs only have two each. Whereas both Spanish adverbs (seriamente and en serio) function as adverbs of manner, the second use of seriamente is that of an adverb of degree while the second use of en serio is that of a statement adverb.

Regarding their properties, we can state that, as with honnêtement/honestamente, all uses of these adverbs as adverbs of manner largely share the same properties, with the exception of extraction by C'est... que in the case of the Spanish adverbs, as Spanish lacks this structure. Moreover, our corpus has shown that the three adverbs are used as adverbs of manner more frequently than as any other type of adverb (103 occurrences out of 200 for sérieusement, 158 occurrences out of 200 for seriamente, and 300 occurrences out of 328 for en serio).

When the speaker states sérieusement ${ }_{1}$, reriamente $_{1}$ and en serio $_{1}(\mathrm{X})$, he is characterizing the realization of the process mentioned in the statement, as well as specifying the manner of accomplishment.

Concerning the second use of sérieusement and seriamente as adverbs of degree, we can see that their use is far more frequent in both languages than that use of honnêtement in French (43 occurrences out of 200 for sérieusement and 44 occurrences out of 200 for seriamente against only 15 occurrences out of 200 for honnêtement). On the other hand, all three adverbs (honnêtement, sérieusement and seriamente) share the same properties when functioning as adverbs of degree, but do not, obviously, have the same meaning. When we state sérieusement $_{2}$ and seriamente se $_{2}(\mathrm{X})$, we assign a high degree to the content of the adjective or the verb modified by the adverb (contrary to when stating honnêtement ${ }_{2}(\mathrm{X})$, when we conveyed an average, or slightly greater than average degree of the content of the adjective modified by the adverb).

Only sérieusement in French and en serio in Spanish can be used as sentence adverbs. According to the data shown by our corpus, this use is always the second most important in French (54 occurrences out of 200 for sérieusement); in Spanish the use of en serio as a sentence adverb is rather infrequent (28 occurrences out of 328), and far less frequent than the uses of seriamente as an adverb of degree shown above. Moreover, both statement adverbs share the same properties and the same meaning: when the speaker states sérieusement $t_{3}$ and en $\operatorname{serio}_{2}(\mathrm{X}, \mathrm{Y})$, he is qualifying the statement and ascribing it a serious quality. 


\section{A common or a different origin for the different uses of these adverbs?}

Although our interest in this paper is mainly to describe the uses and properties of some adverbs in French and Spanish, we can now briefly tackle an especially interesting question. This question concerns the links between the different functions of honnêtement, sérieusement, honestamente, seriamente and en serio, since all of them have more than one use in contemporary French and Spanish. Please note that all these five adverbs have in common a use as an adverb of manner, and that this use remains the most frequent in any case and in any language. Whether an adverb of degree, a statement adverb or both have been added to the adverb of manner, these uses have in no way eliminated the latter.

Thus, do all these uses have the same origin? Have all these adverbs known the same evolution in the history of the French and Spanish languages? Or can we rather consider that there are (two or three) independent uses with their own properties and that we are facing a case of adverbial homonymy? To respond this very last question we shall quote Guimier (1996: 3), when he says that considering these different uses of an adverb a case of homonymy will be against intuition and against the historical origin and evolution of the adverb. ${ }^{2}$

Once the question about the homonymy is solved, we can now turn to the question of the common origin of the functioning of these adverbs. For that purpose, we have looked at the diachrony of the French and the Spanish languages. According to the data provided by FRANTEXT for the French language and by CORDE for the Spanish language, the first use to appear in both languages is as an adverb of manner (12 $2^{\text {th }}$ century for honnêtement, 1293 for honestamente; 1592 for sérieusement, 1634 for seriamente and c. 1550 for en serio), followed by the use as an adverb of degree (1611 for honnêtement, 1592 for sérieusement and 1786 for seriamente); it finally comes both in French and Spanish the use as a sentence adverb $\left(18^{\text {th }}\right.$ century for honnêtement, $20^{\text {th }}$ century for honestamente; 1671 for sérieusement and $20^{\text {th }}$ century for en serio) ${ }^{3}$ (cf. Table 3 ).

\begin{tabular}{|l|c|c|c|}
\hline & Adverb of manner & Adverb of degree & Enunciative adverb \\
\hline honnêtement & $\mathrm{XII}^{\text {th }}$ century & 1611 & $\mathrm{XVIII}^{\text {th }}$ century \\
\hline honestamente & 1293 & - & $\mathrm{XX}^{\mathrm{th}}$ century \\
\hline sérieusement & 1592 & 1592 & 1671 \\
\hline seriamente & 1634 & 1786 & - \\
\hline en serio & circa 1550 & - & $\mathrm{XX}^{\text {th }}$ century \\
\hline
\end{tabular}

Table 3: Diachronic evolution of uses of honnêtement, honestamente, sérieusement, seriamente and en serio

Looking at this table, we can verify that the adverbs in both languages have experienced the same evolution, with a somehow later evolution for the Spanish language compared to the French language.

Then, how can an adverb evolve from its use as an adverb of manner to a use as an adverb of degree and later to a sentence adverb? This evolution seems to be linked to a displacement of

\footnotetext{
2 “Estimer qu'il existe deux adverbes homonymes est contre-intuitif et ne correspond pas à l'histoire du mot. Nous considérons plutôt qu'il s'agit d'un seul et même adverbe qui connait (au moins) deux modes de fonctionnement différents. Nous considérons plutôt qu'il s'agit d'un seul et même adverbe, qui connaît (au moins) deux modes de fonctionnement différents" (Guimier 1996: 3).

3 Cf. Álvarez-Prendes (in press) and Álvarez-Prendes (forthcoming), for more information on this subject.
} 
the adverb to the left of the sentence and a process of subjectification, as described by Traugott.

In this regard, Flament-Boistrancourt (2011: 132) has shown that the displacement of an adverb to the left influences its interpretation in a subjective way: from an objective meaning as an adverb of manner when it is placed to the right of the sentence (as in Lia est intelligente autrement 'She is otherwise smart'), we can access a more subjective meaning as an adverb of degree (as in Lia est autrement intelligente 'She is smart to a high degree') when the adverb has been displaced to the left of the adjective. Schlyter (1977) also points out that emotional adverbs tend to be placed to the left of the sentence, and that such adverbs are frequently related to the speaker's subjectivity. ${ }^{4}$

These issues have been at the heart of the work of several researchers, and most notably of Traugott (Traugott 1995; Traugott/Dasher 2005). Adopting a diachronic perspective, she holds that adverbs of manner ending in -ment/-mente are the root of adverbs of statement functioning as discourse markers, which are the result of a process of subjectification: 'Subjectification' refers to a pragmatic-semantic process whereby 'meanings become increasingly based on the speaker's subjective belief state / attitude toward the proposition', in

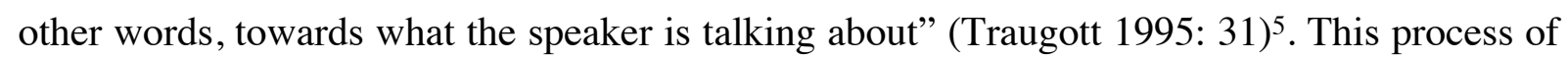
subjectification seems to have been correlated by a displacement of the adverb to the left of the sentence, as explained supra. Recall that a crucial element to determine whether an adverb is functioning as an adverb of manner or as an adverb of degree is its position within the sentence: if placed after the adjective, it will be interpreted as an adverb of manner (Il l'a devancé sérieusement); if placed in front of the adjective, it will be interpreted as an adverb of degree (Il l'a sérieusement devancé dans la course).

To summarize this section, we can say that a process of subjectification in Traugott's sense together with a syntactic displacement of the adverb to the left should be considered in order to explain the passage from an initial use as an adverb of manner to the use as an adverb of degree and later to function as a sentence adverb, as seen in the evolution of the French and Spanish adverbs honnêtement, honestamente, sérieusement, seriamente and en serio.

\section{Conclusion}

In this paper we have succeeded in identifying and characterizing the different uses of several French and Spanish adverbs thanks to a limited number of syntactic and semantic properties. As a result of our analysis, we can state that French adverbs are more multifunctional when compared to Spanish adverbs, as both French adverbs (honnêtement and sérieusement) have three different functions (adverb of manner referring to the subject, adverb of degree and statement adverb) whereas Spanish adverbs have only two functions (adverb of manner

\footnotetext{
4 "Les adverbes émotifs et non-focus ont tendance à figurer aussi loin à gauche que possible"; "Les adverbes qui figurent surtout en position initiale [...] ne peuvent généralement pas être focus, mais sont souvent liés au locuteur" (Schlyter 1977: 134).

5 The Spanish adverbial locution en serio is not, obviously, an adverb ending in -ment and therefore will not fit in Traugott's description. Although this question needs further study, its diachronical evolution seems to have been somehow parallel to that of the adverbs ending in -ment, and that is why we are keeping it in this section concerning subjectification.
} 
referring to the subject and adverb of degree for seriamente; adverb of manner referring to the subject and statement adverb for honestamente and en serio). The historical evolution of these adverbs seems to have been somehow parallel with a however later evolution for the most recent uses of the Spanish adverbs.

\section{Corpora and references to websites}

Real Academia Española: Banco de datos (CREA). Corpus de referencia del español actual. http://www.rae.es [28.01.17].

Real Academia Española: Banco de datos (CORDE). Corpus diacrónico del español actual. http://www.rae.es [28.01.17].

Base textuelle FRANTEXT, ATILF - CNRS \& University of Lorraine. http://www.frantext.fr [28.01.17].

Corpus Le Monde Diplomatique (1978-2006). CD.

Aubert, Brigitte (2006): Funérarium. Paris: Points.

Bekmezian, Hélène (2013): «Le Sénat se prépare à rejeter la réforme des retraites », Le Monde, https:/www.lemonde.fr/politique/article/2013/10/29/le-senat-se-prepare-a-rejeter-la-ref orme-des-retraites_3504781_823448.html [14.10.2018].

Delteil, Gérard (2009): Gombo. Paris: Liana Levi.

Despentes, Virginie (2010): Apocalypse bébé. Paris: Grasset.

Dugain, Marc (2012): Avenue des géants. Paris: Gallimard.

Duretz, Marlène (2013): « Tout à 1 euro », Le Monde, https://www.lemonde.fr/ economie/article/2013/10/19/tout-a-1-euro_3499505_3234.html [14.10.2018].

Este supermercado solo vende productos vencidos (en serio) (2016): https://www.crh oy.com/ambiente/este-supermercado-solo-vende-productos-vencidos-en-serio/ [14.10.2018].

Henry-Levy, Bertrand (2017): Qui a peur du XXI siècle ? Paris: Livres de Poche.

Honnêtement, il peut s'en sortir ? (2014). http://www.drogues-info-service.fr/Les-Forums-dediscussion/Forums-pour-l-entourage/honnetement-il-peut-s-en-sortir [21.12.2014].

Houellebecq, Michel (2010): La carte et le territoire. Paris: Flammarion.

Jonquet, Thierry (2007): Ils sont votre épouvante et vous êtes leur crainte. Paris: Points.

Lemaitre, Pierre (2013): Au revoir là-haut. Paris: Albin Michel.

Le PSG énerve sérieusement Guy Roux (2013): https://www.foot01.com/equipe/paris/le-psgenerve-serieusement-guy-roux,116657 [14.10.2018].

MOOC: Révolution ou Supercherie? (2014): http://sydologie.com/2014/01/mooc-revolutionou-supercherie/ [14.10.2018].

Nègre, Pascal (2010): Sans contrefaçon. Paris: Fayard.

Pancol, Katherine (2006): Les yeux jaunes des crocodiles. Paris: Le livre de poche.

Pennac, Daniel (1997 a): La fée carabine. Paris: Gallimard.

Pennac, Daniel (1997 b): La petite marchande de prose. Paris: Gallimard.

Peras, Delphine (2012): «Avenue des Géants, par Marc Dugain », L'Express, https://www.lex press.fr/culture/livre/avenue-des-geants-de-marc-dugain_1103329.html [14.10.2018].

Psenny, Daniel (2015): « Roberto Saviano: 'Je voulais que le téléspectateur se confronte au mal absolu' », Le Monde, https://www.lemonde.fr/televisions-radio/article/2015/01/16/ 
roberto-saviano-je-voulais-que-le-telespectateur-se-confronte-au-mal-absolu_4558121_ 1655027.html [14.10.2018].

Schmitt, Éric-Emmanuel (1994): La secte des égoïstes. Paris: Albin Michel.

Shepard, Zoé (2011): Absolument débordée. Paris: Points.

Vargas, Fred (2000): Debout les morts. Paris: J'ai lu.

Weber, Bernard (2005): Le souffle des dieux. Paris: Albin Michel.

Ciao.www.ciao.fr/Nokia_3410_Avis_465494 [20.02.2015].

Drogues-info. http://www.drogues-info-service.fr/Les-Forums-de-discussion/Forums-pour-1entourage/honnetement-il-peut-s-en-sortir [20.12.2014].

Etichette. http://www.etichete.info/poussette-a-canne-Xzoga.htm [20.02.2015].

\section{References}

Álvarez-Prendes, Emma (2016): «Différents types d'emplois et propriétés de l'adverbe sérieusement en français contemporain ». Scolia 30: 89-104.

Álvarez-Prendes, Emma (2018): «Polyfonctionnalité adverbiale, grammaticalisation et subjectivation: Le cas de sérieusement, seriamente et en serio », Zeitschrift für romanische Philologie 134 (2): 471-486.

Álvarez-Prendes, Emma (2018): «Le triple fonctionnement de l'adverbe honnêtement en français contemporain: Propriétés et liens avec les marqueurs d'attitude énonciative», Journal of French Language Studies, n.d.: 1-19. doi: 10.1017/S0959269518000224.

Anscombre, Jean-Claude/Ducrot, Oswald (1983): L'argumentation dans la langue. Bruxelles: Mardaga.

Ducrot, Oswald (1980): Les mots du discours. Paris: Éditions de Minuit.

Flament-Boistrancourt, Danièle (2011): «Sinon vs. autrement: Si proches, si loin... ». Langages 184: 129-146.

Gezundhajt, Henriette (2000): Adverbes en -ment et opérations énonciatives: Analyse linguistique et discursive. Bern: Lang.

Guimier, Claude (1996): Les adverbes du français. Le cas des adverbes en -ment. Paris: Ophrys.

Kovacci, Ofelia (1999): «El adverbio». In: Bosque, Ignacio/Demonte, Violeta (eds.): Gramática descriptiva de la lengua española. Madrid, Espasa Calpe: 705-786.

Mélis, Ludo (1983): Les circonstants et la phrase: Étude sur la classification et la systématique des compléments circonstanciels en français moderne. Louvain: Presses universitaires de Louvain.

Molinier, Christian (1990): «Une classification des adverbes en -ment». Langue française 88: $28-40$.

Molinier, Christian (2009): «Les adverbes d'énonciation. Comment les définir et les sousclassifier ». Langue française 161: 9-21.

Molinier, Christian/Levrier, Françoise (2000): Grammaire des adverbes. Description des formes en -ment. Geneva: Droz.

Mørdrup, Ole (1976): «Une analyse non-transformationnelle des adverbes en -ment ». Revue Romane 11: 317-333. 
Nølke, Henning (1983): Les adverbes paradigmatisants: fonction et analyse. Revue Romane 23, numéro spécial.

Quirk, Randolph/Greenbaum, Sidney (1973): A Universal Grammar of English. London: Longman.

Rodríguez Ramalle, María Teresa (2003): La gramática de los adverbios en -mente o cómo expresar maneras, opiniones y actitudes a través de la lengua. Madrid: UAM Ediciones.

Schlyter, Suzanne (1977): La place des adverbes en -ment en français. Thèse de doctorat (non publ.). Konstanz, University of Konstanz.

Traugott, Elizabeth C., (1995): "Subjectification in grammaticalisation". In: Stein, Dieter/Wright, Susan (eds): Subjectivity and Subjectivisation. Cambridge, Cambridge University Press: $31-54$.

Traugott, Elizabeth C./Dasher, Richard B. (2005): Regularity in Semantic Change. Cambridge: Cambridge University Press.

Wilmet, Marc (1997): Une grammaire critique du français. Paris: Hachette. 